\title{
Impact of Alkyl Polyglucosides Surfactant Lutensol GD 70 on Modification of Bacterial Cell Surface Properties
}

\author{
Wojciech Smulek • Ewa Kaczorek • Agnieszka Zgoła-Grzeskowiak • \\ Zefiryn Cybulski
}

Received: 28 October 2014 / Accepted: 26 January 2015 / Published online: 24 February 2015

(C) The Author(s) 2015. This article is published with open access at Springerlink.com

\begin{abstract}
Alkyl polyglucosides, due to their low toxicity and environmental compatibility, could be used in biodegradation of hydrophobic compounds. In this study, the influence of Lutensol GD 70 on the cell hydrophobicity and zeta potential was measured. The particle size distribution and surfactant biodegradation were also investigated. Microbacterium sp. strain E19, Pseudomonas stutzeri strain 9, and the same strain cultivated in stress conditions were used in studies. Adding surfactant to the diesel oil system resulted in an increase of the cell surface hydrophobicity and the formation of cell aggregates (a high polydispersity index). The correlation between cell hydrophobicity and zeta potential in examined samples was not found. The results showed a significant influence of Lutensol GD 70 on the changes in cell surface properties. Moreover, a high biodegradation of a surfactant (over $50 \%$ ) by tested strains was observed. The biodegradation of Lutensol GD 70 depends on the length of both polar and nonpolar chains. A long-term contact with diesel oil of stressed strain
\end{abstract}

W. Smułek $\cdot$ E. Kaczorek $(\bowtie)$

Institute of Chemical Technology and Engineering, Poznan

University of Technology, Berdychowo 4,

60-965 Poznan, Poland

e-mail: ewakaczorek@o2.pl

A. Zgoła-Grzeskowiak

Institute of Chemistry and Technical Electrochemistry,

Poznan University of Technology, Berdychowo 4,

60-965 Poznan, Poland

Z. Cybulski

Department of Microbiology, Greater Poland Cancer Centre, Garbary 15, 61-866 Poznan, Poland modifies not only cell surface properties but also its ability to a surfactant biodegradation.

Keywords Alkyl polyglucosides · Bioavailability Hydrophobicity · Lutensol GD 70 - Surfactant biodegradation $\cdot$ Zeta potential

\section{Introduction}

Alkyl polyglucosides, such as Lutensol GD 70, are nonionic surfactants widely used in industry to form microemulsions, such as all-purposes detergents, cleaners, and personal care products. They are made of natural occurring and renewable materials: carbohydrates and fatty alcohols (von Rybinski and Hill 1998; El-Sukkary et al. 2008). Due to their low toxicity and high biodegradability, they are an environmentally friendly alternative to the conventional surfactants (Bastl-Borrmann and Kroh 2001). Moreover, the addition of these surfactants is one of the possible methods of stimulation of hydrocarbons biodegradation (Edwards et al. 2003).

A lot of hazardous and persistent organic pollutants are hydrophobic and have low solubility in water. Surfactants can increase their solubility and improve a mass transfer between solid and aqueous phases (Zhou and Zhu 2007). On the other hand, surfactants can change the surface properties of bacterial cells, which improves their adhesion to hydrophobic surfaces (Abbasnezhad et al. 2011). Hence, hydrophobic pollutants' degradation ability of the bacteria, may be linked 
to the cell surface properties (Kumari et al. 2012), but not necessarily (Owsianiak et al. 2009). Thus, a surfactant-enhanced remediation (SER) can be a promising method for the remediation of contaminated soils, groundwater, and industrial waste waters (Zhou and Zhu 2007). The determination of cell surface properties, cell adhesion, and cell barrier permeability are also important in another research areas, e.g., in the processes of metals and concrete corrosion, in food industry and in medicine (including cancer diseases diagnosis and treatment) (Harimawan et al. 2013; Hwang et al. 2012; Bañobre-López et al. 2013; Borghi et al. 2011; Hojan and Milecki 2013). In the studies on bacterial adhesion, the hydrophobicity of cell surface is a very often studied property. In order to determine it, several techniques are used, e.g., hydrophobic interaction chromatography, measurement contact angle (van Loosdrecht et al. 1987; Zita and Hermansson 1997), and the method is of microbial adhesion to hydrocarbons-MATH (Rosenberg et al. 1980), which is based on the distribution of cell population between organic and aqueous phases. The more cell is adsorbed in organic phase, the greater hydrophobicity is.

Another property depending on the cell surface properties is zeta potential, usually used in reference to colloids, and it is also an important factor in microbial adhesion. It is possible that the charge neutralization is connected to the enhanced adhesion to the oil interface (Abbasnezhad et al. 2011; Hermansson 1999). The influence of synthetic and natural surfactants on cell surface properties, during biodegradation of hydrophobic pollutants, were widely described (Das and Mukherjee
2007; Feng et al. 2013; Singh and Cameotra 2014; Wang et al. 2013; Li and Zhu 2012). But only a few publications about application of alkyl polyglucosides in bioremediation have been issued (Sałek et al. 2013).

The aim of this study was to determine the changes of cell surfaces properties in the presence of Lutensol GD 70. The differences in hydrophobicity and zeta potential between culture with and without diesel oil were examined. The correlation between these two parameters was also analyzed. Moreover, the subject of the studies was also the biodegradation of Lutensol GD 70 (Table 1), because, for the purpose of bioremediation, the surfactants used should be also biodegradable.

\section{Materials and Methods}

\subsection{Microorganisms}

The bacterial strains Pseudomonas stutzeri strain 9 (JN006140.1) and Microbacterium sp. strain E19 (JQ268557) used in the experiments were isolated from soil samples. They were denoted as Ps9 and E19. The strains were kept on plates with Mueller-Hinton agar. In order to determine the influence of diesel oil, the P. stutzeri strain 9 was kept on agar plates with $50 \mu \mathrm{L}$ of diesel oil, as the only carbon and energy source, for 24 months (subcultured every month to agar plates with mineral medium and diesel oil), and was denoted as Ps9s.
Table 1 Parameters of mass spectrometric detection characteristic to particular analytes
MRM 1 analytical multiple reaction monitoring transition, $M R M$ 2 confirmatory multiple reaction monitoring transition

\begin{tabular}{|c|c|c|c|c|c|}
\hline \multirow[t]{2}{*}{ Glucoside } & \multirow{2}{*}{$\begin{array}{l}\text { Precursor } \\
\text { ion }[\mathrm{M}+ \\
\left.\mathrm{NH}_{4}\right]^{+}(m / z)\end{array}$} & \multicolumn{4}{|c|}{ MRM transitions (precursor ion $m / z \rightarrow$ product ion $m / z$ ) } \\
\hline & & MRM 1 & $\begin{array}{l}\text { Collision } \\
\text { energy (V) }\end{array}$ & MRM 2 & $\begin{array}{l}\text { Collision } \\
\text { energy (V) }\end{array}$ \\
\hline \multicolumn{6}{|c|}{ Lutensol GD 70} \\
\hline $\mathrm{C}_{4} \mathrm{Glu}$ & 254.5 & $254.5 \rightarrow 163.4$ & 13 & $254.5 \rightarrow 145.4$ & 17 \\
\hline $\mathrm{C}_{4} \mathrm{Glu}_{2}$ & 416.5 & $416.5 \rightarrow 163.4$ & 21 & $416.5 \rightarrow 145.4$ & 28 \\
\hline $\mathrm{C}_{4} \mathrm{Glu}_{3}$ & 578.5 & $578.5 \rightarrow 163.4$ & 30 & $578.5 \rightarrow 145.4$ & 37 \\
\hline $\mathrm{C}_{4} \mathrm{Glu}_{4}$ & 740.5 & $740.5 \rightarrow 163.4$ & 41 & $740.5 \rightarrow 145.4$ & 51 \\
\hline $\mathrm{C}_{10} \mathrm{Glu}$ & 338.5 & $338.5 \rightarrow 163.4$ & 15 & $338.5 \rightarrow 145.4$ & 19 \\
\hline $\mathrm{C}_{10} \mathrm{Glu}_{2}$ & 500.5 & $500.5 \rightarrow 163.4$ & 23 & $366.5 \rightarrow 145.4$ & 29 \\
\hline $\mathrm{C}_{10} \mathrm{Glu}_{3}$ & 662.5 & $662.5 \rightarrow 163.4$ & 30 & $662.5 \rightarrow 145.4$ & 38 \\
\hline $\mathrm{C}_{10} \mathrm{Glu}_{4}$ & 824.6 & $824.6 \rightarrow 163.4$ & 41 & $824.6 \rightarrow 145.4$ & 48 \\
\hline
\end{tabular}




\subsection{Growing Conditions}

The culture mineral salts medium, used throughout these studies, was as described previously (Kaczorek et al. 2010). A liquid culture was started by adding a loopful of cells from an agar plate into a $250 \mathrm{~mL}$ Schott Duran ${ }^{\circledR}$ laboratory glass bottles containing $50 \mathrm{~mL}$ of medium. After approximately $24 \mathrm{~h}, 3-5 \mathrm{~mL}$ of this liquid culture was used for the inoculation of the final culture to reach an optical density (measured at $600 \mathrm{~nm}$ ) ca. 0.1 .

\subsection{Particle Size Distribution}

The particle size distribution of the examined cultures was determined by applying the noninvasive back light scattering method. The Zetasizer Nano ZS apparatus (Malvern Instruments Ltd., UK) was used for this purpose. Based on the obtained results, a polydispersity index (PdI) was automatically calculated.

\subsection{Cell Surface Hydrophobicity}

The modified method of microbial adhesion of hydrocarbon (Górna et al. 2011) was used to determine the cell surface hydrophobicity. In bacterial cultures, as the carbon and energy sources were used: fructose, diesel oil, heptane, toluene, Lutensol GD 70 (in different concentrations 6, 60, 120, 240, and $360 \mathrm{mg} \mathrm{L}^{-1}$ ). Moreover, the strains grown on diesel oil and Lutensol GD 70 were also investigated. The bacterial cells from the 7-day cultures were centrifuged ( $8000 \mathrm{rpm}, 5 \mathrm{~min}, 10^{\circ} \mathrm{C}$ ) and washed twice with PUM buffer $\left(19.7 \mathrm{~g} \mathrm{~L}^{-1}\right.$ $\mathrm{K}_{2} \mathrm{HPO}_{4}, 7.26 \mathrm{~g} \mathrm{~L}^{-1} \mathrm{KH}_{2} \mathrm{PO}_{4}, 1.8 \mathrm{~g} \mathrm{~L}^{-1} \mathrm{H}_{2} \mathrm{NCONH}_{2}$, $0.2 \mathrm{~g} \mathrm{~L}^{-1} \mathrm{MgSO}_{4} \cdot 7 \mathrm{H}_{2} \mathrm{O}$ ) in order to remove residual surfactant and carbon sources. Then, the cells were resuspended in the PUM buffer, an optical density was fitted to ca. 1.0. The optical density was measured at $600 \mathrm{~nm}\left(\mathrm{OD}_{600}\right)$ on a Shimadzu UV-Visible Spectrophotometer. Afterwards, $0.5 \mathrm{~mL}$ of heptane was added to $5 \mathrm{~mL}$ of cell suspension and vortexed for $2 \mathrm{~min}$. After $60 \mathrm{~min}$, the $\mathrm{OD}_{600}$ of the aqueous phase was measured. The microbial adhesion to hydrocarbons was calculated as follows:

$H=\left(1-\left(A_{1} / A_{0}\right)\right) \times 100 \%$

$H$-hydrophobicity [\%]; $A_{0}-\mathrm{OD}_{600}$ of initial aqueous phase $[-] ; A_{1}-\mathrm{OD}_{600}$ of aqueous phase after mixing with hexadecane $[-]$.

\subsection{Zeta Potential}

The zeta potential was calculated by using the Zetasizer Nano ZS apparatus (Malvern Instruments Ltd., UK) from the Smoluchowski equation (Miyake et al. 1990), following measurements of electrophoresis mobility. The bacterial strains were grown on different carbon sources: fructose, diesel oil, heptane, toluene, Lutensol GD 70 (in different concentrations 6, 60, 120, 240, and $360 \mathrm{mg} \mathrm{L}^{-1}$ ) and in systems with diesel oil and Lutensol GD 70. The bacterial cells from the 7-day cultures were centrifuged ( $8000 \mathrm{rpm}, 5 \mathrm{~min}, 10^{\circ} \mathrm{C}$ ) and washed twice with PUM buffer $\left(19.7 \mathrm{~g} \mathrm{~L}^{-1} \mathrm{~K}_{2} \mathrm{HPO}_{4}, 7.26 \mathrm{~g} \mathrm{~L}^{-1}\right.$ $\mathrm{KH}_{2} \mathrm{PO}_{4}, 1.8 \mathrm{~g} \mathrm{~L}^{-1} \mathrm{H}_{2} \mathrm{NCONH}_{2}, 0.2 \mathrm{~g} \mathrm{~L}^{-1} \mathrm{MgSO}_{4}$. $7 \mathrm{H}_{2} \mathrm{O}$ ) in order to remove residual surfactant and carbon sources. Then, the cells were resuspended in the PUM buffer, and $\mathrm{OD}_{600}$ were fitted to ca. $1.0\left(10^{8} \mathrm{cfu} \mathrm{mL}^{-1}\right)$.

\section{Results and Discussion}

\subsection{Particle Size Distribution}

The particle size distribution for all tested strains is shown in Fig. 1a-c. In the case of the nonstressed strains (Ps9 and E19), there was no significant difference in distribution spectra between cultures with fructose, diesel oil, and the surfactant only. In the presence of diesel oil and Lutensol GD 70, the particles are minor and two groups can be distinguished-about 100 and $700 \mathrm{~nm}$. For the stressed strain (Ps9s), the particle size distributions are similar in cultures with fructose and Lutensol GD 70, and other with diesel oil. The addition of the surfactant had no influence. According to polydispersity index $(\mathrm{PdI})$, the most homogeneous samples are the ones with Lutensol GD 70 only (for Ps9-0.031, for Ps9s-0.218, for E19-0.201). For each strain, the samples with Lutensol GD 70 and diesel oil as well (for Ps9-0.728, for Ps9s-1.000, for E19-0.427) are the less homogeneous.

\subsection{Changes in Cell Surface Hydrophobicity}

The cell surface hydrophobicity of examined strains strongly depends on the carbon source used (Fig. 2). In the presence of easily acceptable compounds, such as fructose, hydrophobicity of all strains did not exceed $20 \%$. In the samples from cultures with hydrocarbons, the hydrophobicity increased but it depended on the 
Fig. 1 Particle size distribution during: a Pseudomonas stutzeri strain 9 (Ps9), b stressed

Pseudomonas stutzeri strain 9 (Ps9s), c Microbacterium sp. strain E19 (E19) growth on a different carbon sources: $F$-with fructose, $D O$ - with diesel oil, $\mathrm{DO}+\mathrm{L}$ - with diesel oil and Lutensol GD 70 (120 $\mathrm{mg} \mathrm{L}^{-1}$ ), $L$-with Lutensol GD 70 (120 mg L $\left.{ }^{-1}\right)$. For each sample, three measurements were made, the accuracies of the measurements being $\pm 0.01 \mathrm{mV}$
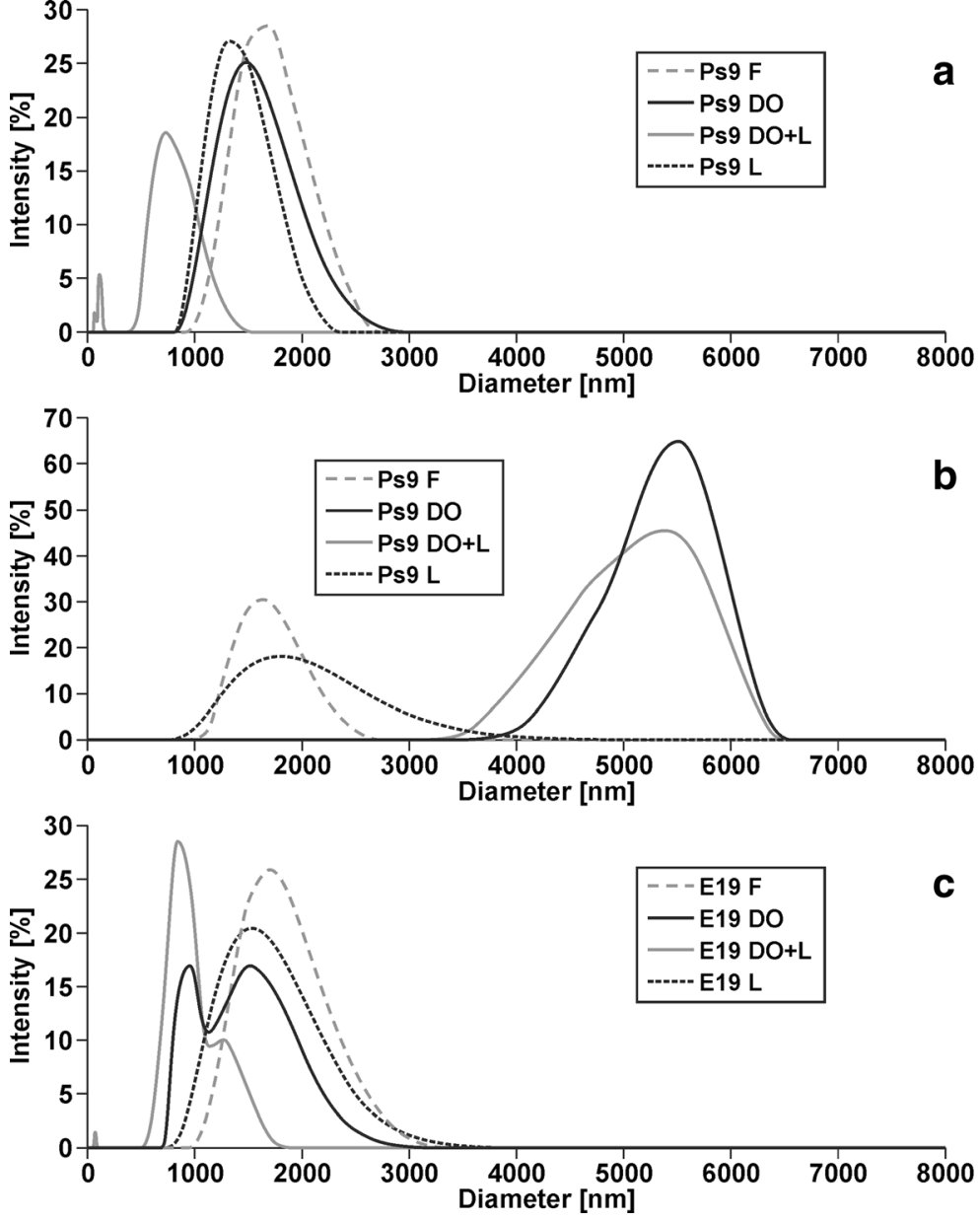

tested strain. Hydrophobicity of P. stutzeri (Ps9) increased in the presence of diesel oil, toluene, and heptane, and reached values between 30 and $40 \%$. The hydrophobicity of the same strain grown in stress conditions (Ps9s) reached $80 \%$ in the presence of diesel oil and $65 \%$ in heptane, but it was very low in the presence of toluene. It can suggest that in stress conditions, it has adapted more to aliphatic hydrocarbons, than to aromatic compounds like toluene. Microbacterium sp. strain E19 had very low hydrophobicity (less than $10 \%$ ) in all samples except for the one with toluene.

The influence of Lutensol GD 70 on the cell surface hydrophobicity is very significant (Fig. 3). For all strains in cultures with a surfactant, only the strains with hydrophilic properties (less than $20 \%$ ) were dominating, even compared to cultures with fructose. In the presence of diesel oil and a surfactant, the hydrophobicity of all strains grew up and for Ps9s were nearly $100 \%$.
However, the correlation between the surfactant concentration and the value of hydrophobicity was not observed.

The results observed differ from those obtained by other researchers. The addition of synthetic surfactants, like Triton X-100 and Tween 80, causes an increase of the cell surface hydrophobicity for Pseudomonas aeruginosa (Yuan et al. 2007). A similar effect was observed for Tween 80 or sodium dodecyl benzene sulfonate and Citobacter sp. SA01 (Li and Zhu 2012). On the other hand, Feng et al. (2013) found that rhamnolipid and tergitol increased Pseudomonas putida 852 hydrophobicity, but decreased the hydrophobicity of Rhodococcus erythropolis 3586 . The first strain in culture without surfactants was hydrophilic, the second-hydrophobic. The differences can be caused by different surfactant adsorption mechanisms. 
Fig. 2 Bacterial adhesion to hydrocarbon for Pseudomonas stutzeri strain 9 (PS9), the same strain grown in stress conditions (PS9s) and Microbacterium sp. strain E19 (E19) after growth on different carbon sources: diesel oil, fructose, toluene, and heptane. Process was carried out at $25{ }^{\circ} \mathrm{C}$ for 7 days. The results have an absolute (100\%) quantitative value. Each value is the average of triplicate determinations with the standard deviation in the range of $\pm 1.8 \%$

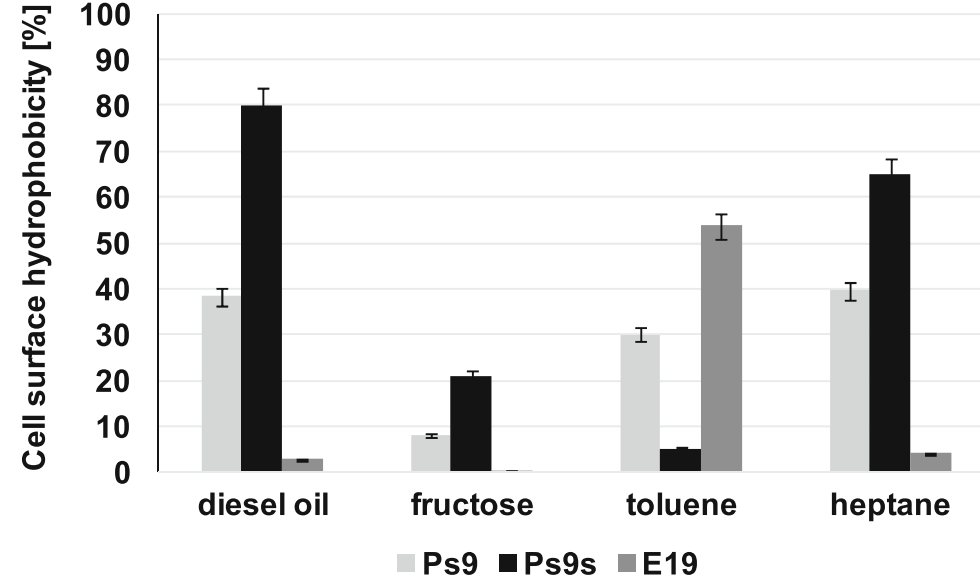

the value of zeta potential was lower in cultures with hydrocarbon than in cultures with fructose, but there is no similar correlation for another strains.

The addition of a surfactant emphatically changed the zeta potential (Fig. 3), especially for Ps9s strain in

The zeta potential in samples with different carbon $22 \mathrm{mV}$ (Fig. 4). For Microbacterium sp. strain E19,

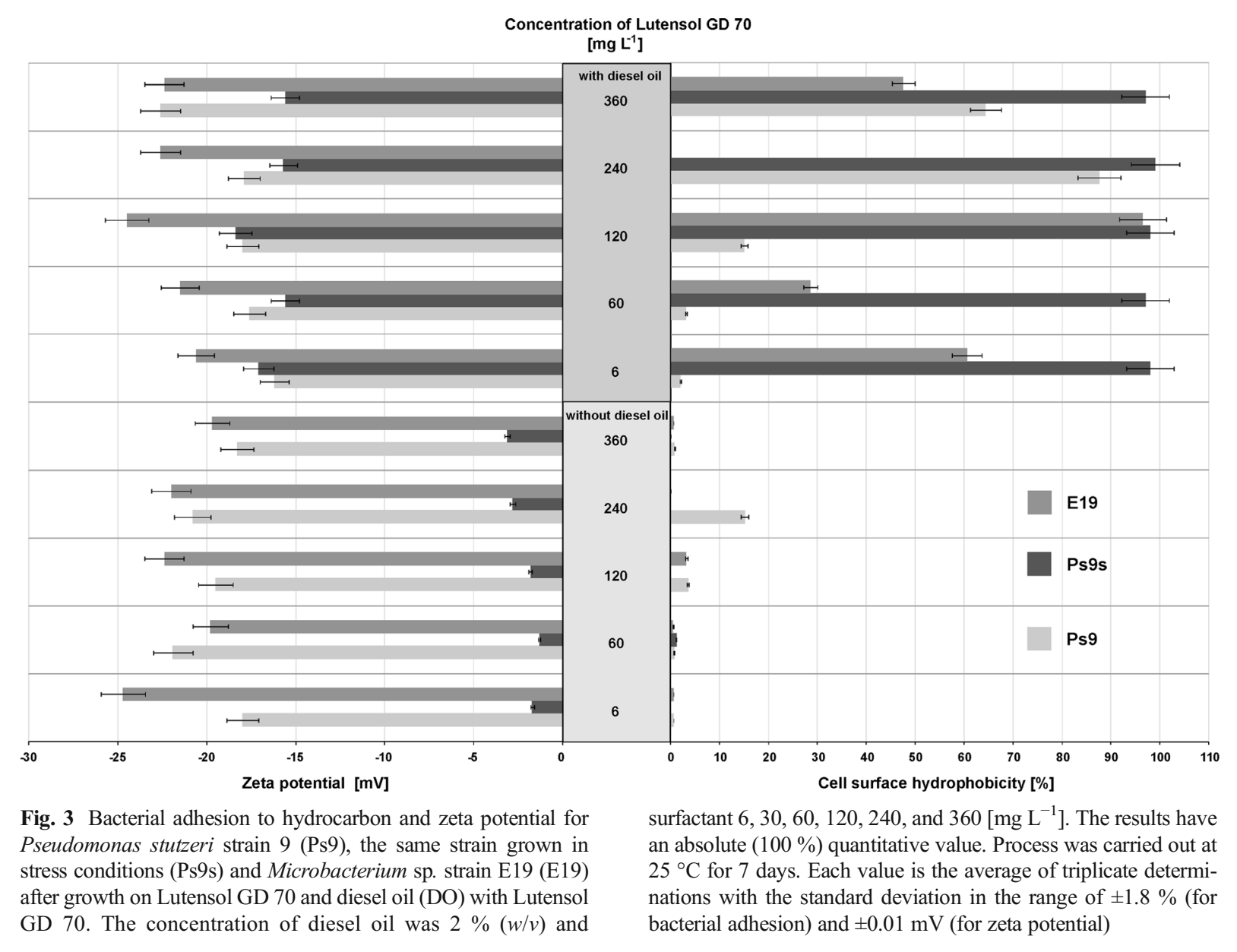


Fig. 4 Zeta potential for Pseudomonas stutzeri strain 9 (Ps9), the same strain grown in stress conditions (Ps9s) and Microbacterium sp. strain E19 (E19) after 7 days of experiment carried out with different carbon sources: diesel oil, fructose, toluene, and heptane. For each sample, three measurements were made, the accuracies of the measurements being $\pm 0.01 \mathrm{mV}$

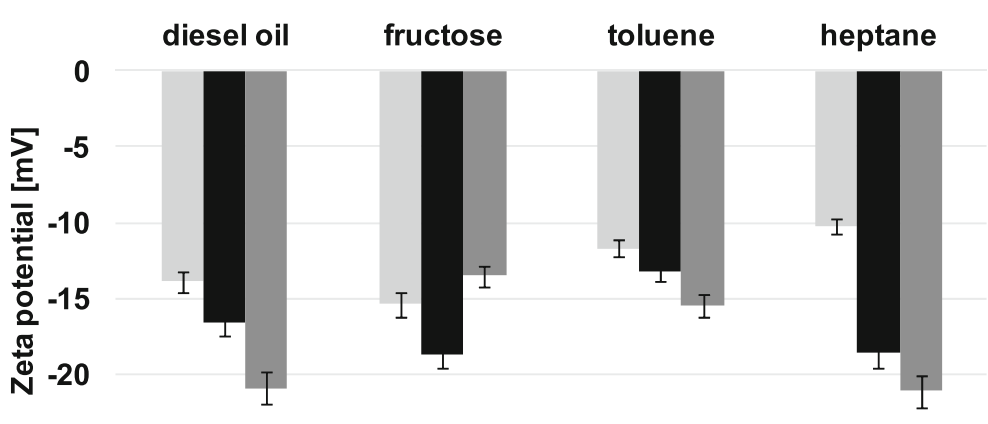

$-25$

Ps9 aps9 E19

cultures with surfactant only. In these samples, the zeta potential increased to more than $-5 \mathrm{mV}$. It is possible that it was caused by the changes in cell well structure in stress conditions. On the other hand, a decrease of this parameter was observed for Ps9 strain. For all strains in systems with diesel oil and a surfactant, the values fluctuated between -15 and $-25 \mathrm{mV}$.

Comparing with the results for hydrocarbon degrading strains Burkholderia cepacia and
Burkholderia multivorans grown with Triton X-100, Igepal CA 630, and Tween 80 (Mohanty and Mukherji 2012), it can be also noticed that the addition of a surfactant changes the zeta potential of the cell surface but they depend on tested strain and surfactant as well. The influence of biosurfactants like rhamnolipids on zeta potential during diesel oil biodegradation was also observed (Zhong et al. 2007). The similar effect of reducing zeta potential by Lutensol GD 70 for strain

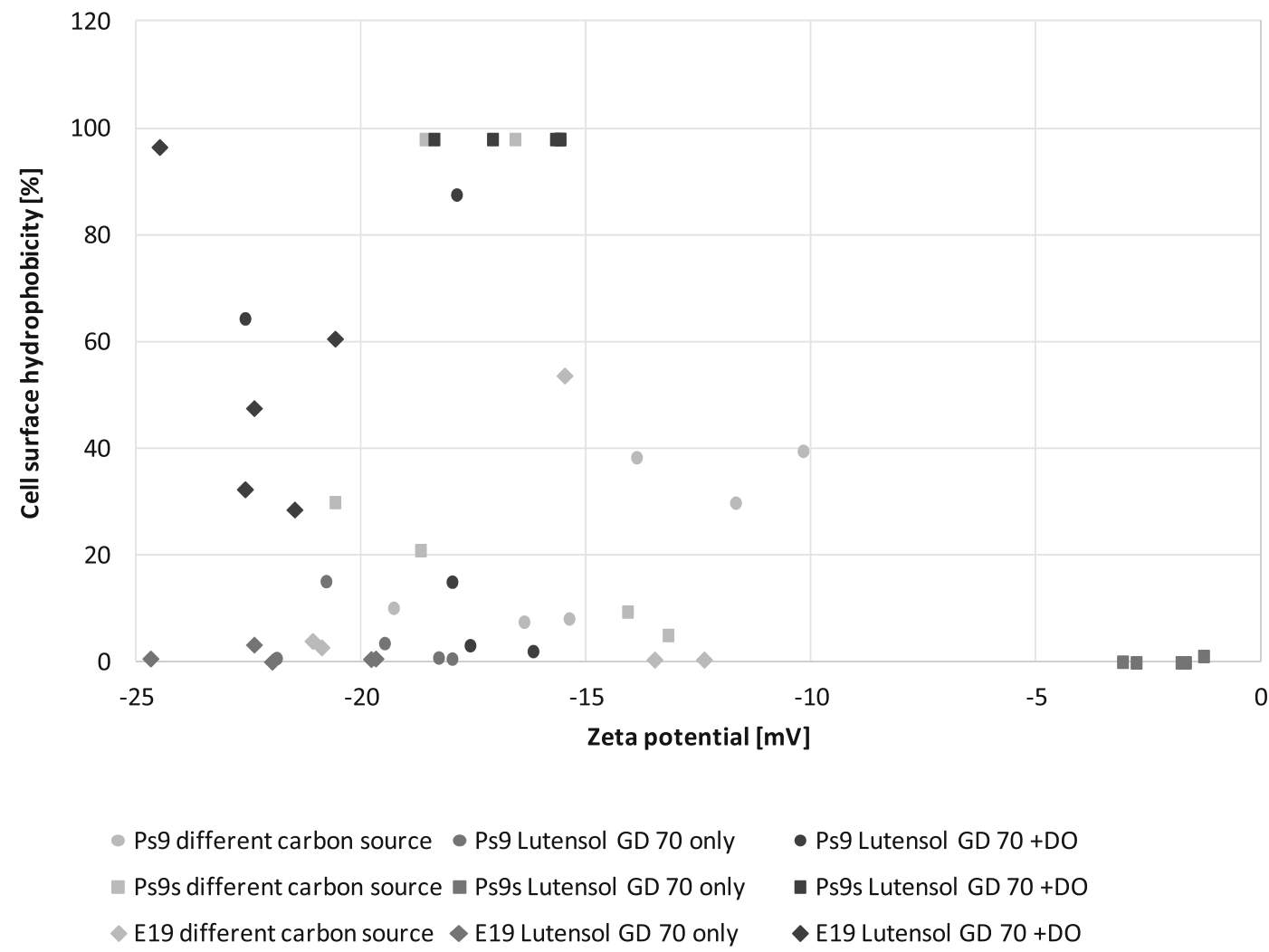

Fig. 5 Correlation between cell surface hydrophobicity and zeta potential for Pseudomonas stutzeri strain 9 (Ps9), the same strain grown in stress conditions (Ps9s) and Microbacterium sp. strain E19 (E19) 
Ps9s was observed in system with Pseudomonas fluorescens strain LP6a and some cationic surfactants (Hermansson 1999).

Moreover, in Fig. 5, a relationship between two measured cell surface properties - hydrophobicity and zeta potential, is shown. In general and in any specified set of data, no correlation has been observed.

\subsection{Surfactant Biodegradation}

The biodegradation of Lutensol GD 70 by tested bacterial strains depends on the length of both polar and nonpolar chains. However, in most tests, no considerable dependence between the biodegradation and the length of alkyl or glucose chain can be found. The biodegradation of Lutensol GD 70 by the Ps9 strain is not high at both concentrations of this surfactant, i.e., 120 and $360 \mathrm{mg} \mathrm{L}^{-1}$ (Fig. 6a, b). Moreover, the increased amount of Lutensol GD 70 led to its lower biodegradation. On the other hand, the addition of diesel oil to the samples had no influence on the sample containing $120 \mathrm{mg} \mathrm{L}^{-1}$ of Lutensol GD 70, and only a
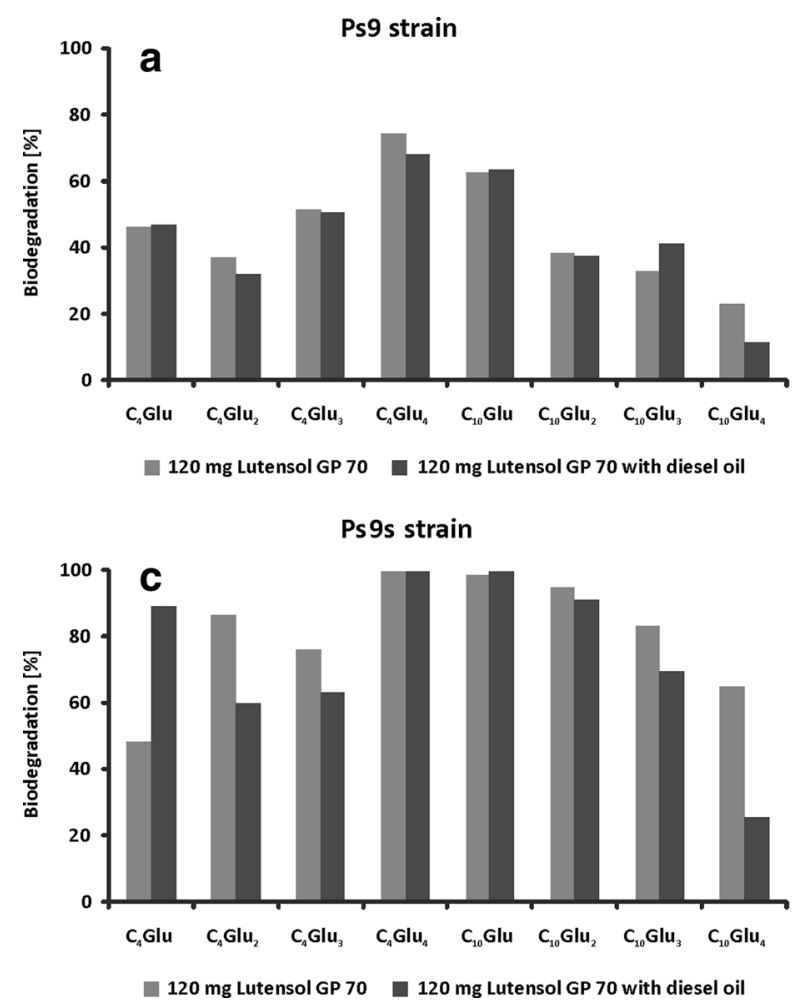

Fig. 6 Biodegradation of Lutensol GP 70 with and without diesel oil using: a, b Pseudomonas stutzeri strain 9 (Ps9) and c, d the same strain grown in stress conditions (PS9s). The alkyl small increase of biodegradation was observed for the sample containing $360 \mathrm{mg} \mathrm{L}^{-1}$ of Lutensol GD 70.

The biodegradation of Lutensol GD 70 by the stressed Ps9 strain was relatively high at both concentrations of this surfactant (Fig. 6c, d). There was no difference between samples containing 120 and $360 \mathrm{mg} \mathrm{L}^{-1}$ of Lutensol GD 70. The addition of diesel oil had no influence on the biodegradation of particular homologues belonging to Lutensol GD 70 at $120 \mathrm{mg} \mathrm{L}^{-1}$ subjected to the test. Only the biodegradation of $\mathrm{C}_{4} \mathrm{Glu}$ was higher, while for the rest of the homologues, the biodegradation was lower or the same, like for the sample without diesel oil. A considerable difference was observed for the sample containing $360 \mathrm{mg} \mathrm{L}^{-1}$ of Lutensol GD 70 with diesel oil degraded by the stressed Ps9 bacterial strain. Although the results for $\mathrm{C}_{10} \mathrm{Glu}_{1-4}$ homologues were similar to those obtained at $120 \mathrm{mg} \mathrm{L}^{-1}$ of Lutensol GD 70, considerably lower biodegradation was noted for $\mathrm{C}_{4} \mathrm{Glu}_{1-4}$ homologues with shorter alkyl chain. Nevertheless, it can be concluded that the stress put on bacterial strain has greater influence on the biodegradation of Lutensol GD 70 than
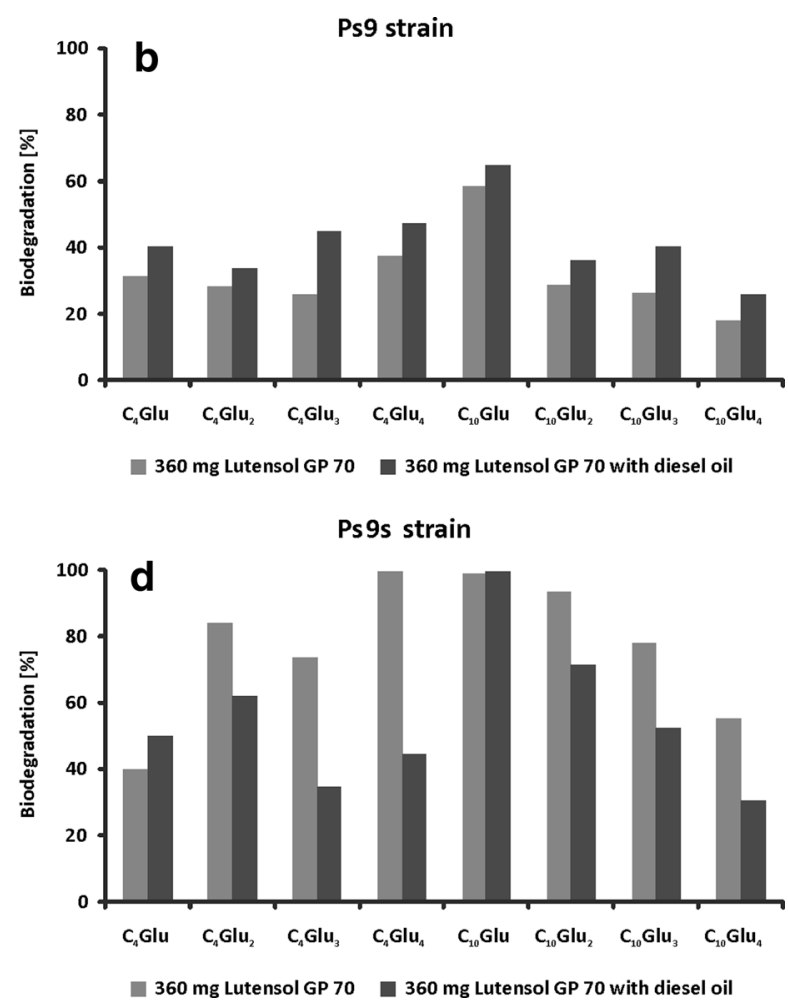

polyglucosides concentration was 120 and $360 \mathrm{mg} \mathrm{L}^{-1}$ and diesel oil $2 \%(w / v)$. Process was carried out at $25{ }^{\circ} \mathrm{C}$ for 7 days 
both concentration of Lutensol GD 70 and the addition of diesel oil.

No publications about Lutensol GD 70 biodegradation were found. Jurado et al. (2011) investigated biodegradation of another alkyl polyglucoside, Glucopon 650. In 7-day cultures inoculated with an active sludge, the biodegradation of surfactant was about $60 \%$ at concentrations less than $50 \mathrm{mg} \cdot \mathrm{L}^{-1}$. But at the concentration $75 \mathrm{mg} \cdot \mathrm{L}^{-1}$ and $100 \mathrm{mg} \cdot \mathrm{L}^{-1}$ the biodegradation was about $10 \%$. Zgoła-Grześkowiak et al. (2008) using modified OECD screening test, observed after one week nearly $100 \%$ biodegradation of all fractions of Glucopon 215 and Glucoon 600. Qin et al. (2006) using activated sludge obtained about $90 \%$ biodegradation of short chained (C8 and $\mathrm{C} 10)$ fractions. Our results have shown that better results of surfactant biodegradation were obtained for the strain with long-term contact with diesel oil.

\section{Conclusions}

Alkyl polyglucosides, such as Lutensol GD 70, can be applied in the environment as a factor supporting the bioavailability of hydrophobic carbon sources. It is really biodegradable by microorganisms. This surfactant in different way modifies cell surface of tested strains. Adding it to the diesel oil system resulted in an increase of cell surface hydrophobicity and the formation of cell aggregates (a high polydispersity index). Moreover, the correlation between surfactant concentrations and cell surface hydrophobicity was not observed. Furthermore, a long-term contact with diesel oil (24 months) modifies not only cell surface properties of tested strain but also its ability of surfactant biodegradation.

Acknowledgments This study was supported by The National Science Centre awarded by decisions number DEC-2012/07/B/ NZ9/00950

Open Access This article is distributed under the terms of the Creative Commons Attribution License which permits any use, distribution, and reproduction in any medium, provided the original author(s) and the source are credited.

\section{References}

Abbasnezhad, H., Gray, M. R., \& Foght, J. M. (2011). Influence of adhesion on aerobic biodegradation and bioremediation of liquid hydrocarbons. Appl Microbiol Biotechnol, 92, 653675.
Bañobre-López, M., Teijeiro, A., \& Rivas, J. (2013). Magnetic nanoparticle-based hyperthermia for cancer treatment. Rep Pract Oncol Radiother, 18, 397-400.

Bastl-Borrmann, R., \& Kroh, L. W. (2001). Novel enzymatic assay for determination of alkyl polyglycosides with short chain fatty alcohols. Fresen J Anal Chem, 371, 939-943.

Borghi, E., Sciota, R., Biassoni, C., Cirasola, D., Cappelletti, L., Vizzini, L., Boracchi, P., \& Morace, G. (2011). Cell surface hydrophobicity: a predictor of biofilm production in Candida isolates? J Med Microbiol, 60, 689-690.

Das, K., \& Mukherjee, A. K. (2007). Differential utilization of pyrene as the sole source of carbon by Bacillus subtilis and Pseudomonas aeruginosa strains: role of biosurfactants in enhancing bioavailability. J Appl Microbiol, 102, 195-203.

Edwards, K. R., Lepo, J. E., \& Lewis, M. A. (2003). Toxicity comparison of biosurfactants and synthetic surfactants used in oil spill remediation to two estuarine species. Mar Pollut Bull, 46, 1309-1316.

El-Sukkary, M. M. A., Syed, N. A., Aiad, I., \& El-Azab, W. I. M. (2008). Synthesis and characterization of some alkyl polyglycosides surfactants. J Surfactants Deterg, 11, 129-137.

Feng, W., Swift, S., \& Singhal, N. (2013). Effects of surfactants on cell surface tension parameters and hydrophobicity of Pseudomonas putida 852 and Rhodococcus erythropolis 3586. Colloid Surf B, 105, 43-50.

Górna, H., Ławniczak, Ł., Zgoła-Grześkowiak, A., \& Kaczorek, E. (2011). Differences and dynamic changes in the cell surface properties of three Pseudomonas aeruginosa strains isolated from petroleum-polluted soil as a response to various carbon sources and the external addition of rhamnolipids. Bioresour Technol, 102, 3028-3033.

Harimawan, A., Zhong, S., Lim, C.-T., \& Ting, Y.-P. (2013). Adhesion of $B$. subtilis spores and vegetative cells onto stainless steel - DLVO theories and AFM spectroscopy. $J$ Colloid Interf Sci, 405, 233-241.

Hermansson, M. (1999). The DLVO theory in microbial adhesion. Colloid Surf B, 14, 105-119.

Hojan, K., \& Milecki, P. (2013). Opportunities for rehabilitation of patients with radiation fibrosis syndrome. Rep Pract Oncol Radiother, 19, 1-6.

Hwang, G., Ahn, I. S., Mhin, B. J., \& Kim, J.-Y. (2012). Adhesion of nano-sized particles to the surface of bacteria: mechanistic study with the extended DLVO theory. Colloids Surf B, 97, 138-144.

Jurado, E., Fernandez-Serrano, M., Nffez-Olea, J., Lechuga, M., Jimenez, J. L., \& Rios, F. (2011). Effect of concentration on the primary and ultimate biodegradation of alkylpolyglucosides in aerobic biodegradation tests. Water Environ Res, 83, 154-161.

Kaczorek, E., Urbanowicz, M., \& Olszanowski, A. (2010). The influence of surfactants on cell surface properties of Aeromonas hydrophila during diesel oil biodegradation. Colloid Surf B, 81, 363-368.

Kumari, B., Singh, S. N., \& Singh, D. P. (2012). Characterization of two biosurfactant producing strains in crude oil degradation. Process Biochem, 47, 2463-2471.

Li, F., \& Zhu, L. (2012). Effect of surfactant-induced cell surface modifications on electron transport system and catechol 1,2-dioxygenase activities and phenanthrene biodegradation by Citrobacter sp. SA01. Bioresour Technol, 123, 42-48. 
Miyake, Y., Tsunoda, T., Minagi, S., Akagawa, Y., Tsuru, H., \& Suginaka, H. (1990). Antifungal drugs affect adherence of Candida albicans to acrylic surfaces by changing the zetapotential of fungal cells. FEMS Microbiol Lett, 69, 211-214.

Mohanty, S., \& Mukherji, S. (2012). Alteration in cell surface properties of Burkholderia spp. during surfactant-aided biodegradation of petroleum hydrocarbons. Appl Microbiol Biotechnol, 94, 193-204.

Owsianiak, M., Szulc, A., Chrzanowski, Ł., Cyplik, P., Bogacki, M., Olejnik-Schmidt, A. K., \& Heipieper, H. J. (2009). Biodegradation and surfactant-mediated biodegradation of diesel fuel by 218 microbial consortia are not correlated to cell surface hydrophobicity. Appl Microbiol Biotechnol, 84, 545-553.

Qin, Y., Zhang, G., Zhang, J., Zhao, Y., \& Zhao, J. (2006). Primary aerobic biodegradation of linear and oxo alcohol alkylpolyglucosides (APG). Jour Surf Deter, 9, 227-230.

Rosenberg, M., Gutnick, D., \& Rosenberg, E. (1980). Adherence of bacteria to hydrocarbons: a simple method for measuring cell-surface hydrophobicity. FEMS Microbiol Lett, 9, 29-33.

Sałek, K., Zgoła-Grześkowiak, A., \& Kaczorek, E. (2013). Modification of surface and enzymatic properties of Achromobacter denitrificans and Stenotrophomonas maltophilia in association with diesel oil biodegradation enhanced with alkyl polyglucosides. Colloid Surf B, 111, 36-42.

Singh, A. K., \& Cameotra, S. S. (2014). Influence of microbial and synthetic surfactant on the biodegradation of atrazine. Environ Sci Pollut R, 21, 2088-2097.

van Loosdrecht, M. C. M., Lyklema, J., Norde, W., Schraa, G., \& Zehnder, A. J. B. (1987). The role of bacterial cell wall hydrophobicity in adhesion. Appl Environ Microb, 53, 1893-1897.

von Rybinski, W., \& Hill, K. (1998). Alkyl polyglycosides properties and applications of a new class of surfactants. Angew Chem Int Edit, 35, 1328-1345.

Wang, D., Chen, L., Zhou, L., Hai, L., \& Li, C. (2013). Effects of rhamnolipid on petroleum degradation of compound microbial inoculant. Chinese J Environ Eng, 7, 4121-4126.

Yuan, X. Z., Ren, F. Y., Zeng, G. M., Zhong, H., Fu, H. Y., Liu, J., $\& \mathrm{Xu}, \mathrm{X}$. M. (2007). Adsorption of surfactants on a Pseudomonas aeruginosa strain and the effect on cell surface lypohydrophilic property. Appl Microbiol Biotechnol, 76, 1189-1198.

Zgoła-Grześkowiak, A., Grześkowiak, T., Frańska, M., Rząsa, A., \& Lukaszewski, Z. (2008). Investigations on the biodegradation of alkylpolyglucosides by means of liquid chromatography-electrospray mass spectrometry. Biodegradation, 19, 635-642.

Zhong, H., Zheng, G., Yuan, X. Z., Fu, H., Huang, G. H., \& Ren, F. Y. (2007). Adsorption of dirhamnolipid on four microorganisms and the effect on cell surface hydrophobicity. Appl Microbiol Biotechnol, 77, 447-455.

Zhou, W., \& Zhu, L. (2007). Efficiency of surfactant-enhanced desorption for contaminated soils depending on the component characteristics of soil-surfactant-PAHs system. Environ Pollut, 147, 66-73.

Zita, A., \& Hermansson, M. (1997). Effects of bacterial cell surface structures and hydrophobicity on attachment to activated sludge flocs. Appl Environ Microb, 152, 299306. 